\title{
Concentration of Banking Sector and Loan Markups in Short Term: An Example from Poland
}

\author{
Krzysztof Drachal \\ Warsaw University of Technology \\ Faculty of Mathematics and Information Science \\ 00 - 662 Warszawa, ul. Koszykowa 75, Poland \\ E-mail: k.drachal@mini.pw.edu.pl
}

\begin{abstract}
The aim of this paper is to present an analysis of the relationship between concentration of the banking sector and banks' markups on offered loans. The markup is understood as the difference between the rate offered by banks and the reference rate fixed by the Monetary Policy Council. The period between 2009 and 2013 was analyzed. Monthly data from the Polish banking sector were considered. This paper also consists of the literature review, which focuses on the mortgage market. The methodology used for the analysis is based mainly on simple linear regression techniques. It is found that such methods are not sufficient to give conclusive answers. Therefore additional future research is proposed.
\end{abstract}

Keywords: concentration of banking sector, loan markup, Poland

JEL codes: E32, E40, E50, G21

\section{Introduction}

The process of consolidation of banks has both advantages and disadvantages. Consolidated banks can use their assets more efficiently. They are also more competitive, especially on the global market, where a player must be sufficiently large in order to participate. This might provide some benefits for customers also. Through mergers and takeovers, banks can become more innovative and they can diversify their capital. Non-efficient branches are closed or taken over by profitable and efficient banks, which leads to the optimization of the banking sector as a whole.

On the other hand, concentration leads a market towards oligopoly. As a result, banks gain the advantage over consumers. They can abuse the financial market and put too much pressure on the whole economy. As a result, there is no common opinion on the effect of concentration of the banking sector.

However, it has to be remembered that the Polish banking sector has been dynamically evolving since 1989 . Not only have the processes associated with globalization intensified since then, but this time period was also marked by a transition in economy. In order to switch towards a capitalist economy, banks were privatized. There has also been a significant role of foreign capital in these processes. 
Before 1993, there were many banks. Consolidation processes began mainly because of the low level of capital held by these banks, as well as high competition from foreign banks. Also, the number of banks was inadequate to suit market needs. Moreover, economies of scale played an important role.

There were 43 mergers and takeovers in the banking sector between 1993 and 2004 in Poland. As a result, the number of banks controlled by domestic investors declined from 48 to 8 in this period. On the other hand, the number of banks controlled by foreign investors increased from 10 to 41 (Kraciuk, 2006; Pawłowska, 2003; Stępień, 2004).

Therefore it is interesting to analyze some recent, short-term (noticed between 2010 and 2013) processes with a stress on costs paid by customers. In this paper the increase of concentration ratio of the five biggest banks (measured by the share in total banking assets), is analyzed with regards to whether it can significantly influence the difference between interest rates offered by banks to customers and the reference rate fixed by the Monetary Policy Council. Some special attention is paid to the impact on housing loans rates.

\section{Literature review}

Banks consolidate due to the potential benefits. There are various explanations for this process (Micek, 2002), but the most important ones are: corporate synergy, geographic expansion, product diversification, cost reduction, new market expansion, increase in the share of credit and deposit market, prestige from being the leader, competitive advantage, reducing information asymmetry.

The paper by Kokoszczyński (2001) presents a concise historical review of consolidation processes in the Polish banking sector after the fall of communism in Poland. Currently the Polish banking sector is quite stable and concentration is rather stabilized. Its profitability is good. It has increased especially after the EU accession (Piocha, Radlińska, 2010).

\subsection{Advantages and disadvantages of the concentration}

Lakic (2013) argues that bank concentration leads to various pathological situations: abuse of the credit system, mechanism of interest rate, derivative market, etc. High banking concentration leads towards monopoly. In practice, there is no real control over such huge institution by the official authorities. Big banks, knowing that they are "too big to fail", can take exceedingly high risks (Carletti, Hartmann, 2002).

Herring and Wachter (1998) argue that real estate cycles and banking crises are significantly correlated. They warn that if banks hold too much of the country's assets, it might have severe consequences on the nations economy. Garmaise and Moskowitz (2004) analyzed data from 11 states in U.S. between 1992 and 
1999. They focused on the social costs of bank mergers. They found that bank mergers usually lead to worsening credit terms and therefore to less development and investment. These may decrease real estate prices and harm poorer households. In the longer term it increases the number of property crimes. In fact, mergers reduce bank competition which has a positive impact on credit terms.

Allen et al. (2012) have discusses that a merger has an impact on customers by worsening the negotiations process. But the overall impact on average rates is small. The market may still remain competitive. In the case of mortgage rates, financial literacy of customers plays an important role.

Basing on the SCP (structure-conduct-perform) paradigm, Allen et al. (2001) argue that there are negative social effects arising from high banking sector concentration. Ferreira (2013) also found that an increase in bank concentration decreases bank efficiency. This is because of small competition present in concentrated markets.

On the other hand, bank concentration can expand access to long-term credit. Bank concentration can play a positive role on the market, by influencing a firms' debt structure (González, González, 2008). Levine (2004) has found that entry restrictions on foreign banks can lead to an increase in loan rates. On the other hand, such restriction on domestic banks do not increase loan rates.

Cipollini and Fiordelisi (2008) analyzed over 18000 banks (also cooperative ones) from Austria, Belgium, France, Germany, Italy and Spain and their activity between 1997 and 2005. They have found that there is a negative correlation between bank concentration and financial distress. But this is mainly due to the role of savings and cooperative banks. If the sample is restricted to commercial and listed banks there is a positive correlation between bank concentration and financial distress. Moreover, Uhde and Heimeshoff (2009) have found that the increase in banking concentration lead to worsening of financial soundness of banks. Their research is based on a sample of more than 2600 banks from the EU-25 for the period between 1997 and 2005.

It is usually thought that a high ratio of state-owned banks results in less access to credit and reduced financial system stability. On the other hand, foreign-owned banks are perceived as the ones offering competitive prices and accessible credits for customers (Berger et al., 2004; Santillán Salgado, 2011).

Based on the data from 70 countries for the period between 1980 and 1997, Beck et al. (2003) has concluded that concentration in the banking sector reduces the risk of crisis. Decreasing the regulations of restrictions on bank competition and bank activities also has positive results for the economy. Moreover, deregulations can intensify the competition of public institutions. 
A high concentration in the banking sector can lead to higher profitability of various financial institutions. Also, supervision and control by the authorities is easier. As a result, there is a smaller risk of crisis (Allen, Gale, 2000).

\subsection{Impact on housing market}

Renaud (2009) emphasizes that for the first time in the world history more people live in urban areas than in rural areas. As a result, the financial system connected with housing becomes an increasingly important part of the whole economy. Housing loans will increase, because urban expansion intensifies. This cannot be covered by government expenditures solely. On the other hand, D'Arista (2009) has noticed that the traditional role of a bank as a lending institution declines. Household savings are not invested in banking deposits, but rather in mutual and pension funds.

Sørensen and Lichtenberger (2007) have found slight evidence that smaller concentration in banking sector might lead to lower mortgage rates. Their research is based on the Eurozone countries. Calza et al. (2009) have found that the features of residential mortgage markets differ significantly across industrialized countries. Moreover, the transmission of monetary policy shocks to residential investment and house prices is stronger in countries with more flexible and developed mortgage markets.

Favara and Imbs (2010) have found that branch banking deregulation can lead to an increase in house prices, due to an increase in mortgages. They have researched house prices in the U.S. between 1994 and 2005. The bank branching deregulation was measured by methods of Rice and Strahan (2010). Bergstresser (2008) has analyzed the period between 1980 and 1994 in the U.S. It has been found that the increase in bank concentration reduced the flow of bank capital to construction and land development loans. Iacoviello (2002) has found significant impact of tight monetary policy on the decrease of real house prices in France, Germany, Italy, Spain, Sweden and UK for the periods covering late 1970s till 1998.

The debate on links between housing and macroeconomics dates back to Fischer (1933) and his debt deflation theory. Residential capital stock plays an important role in the economy, housing expenses constitute an important part of household expenditures, etc. (Chetty, Szeidl, 2004; Greenwood, Hercowitz, 1991; Skinner, 1994). The relationship of macroeconomics and the housing market has been extensively studied for developed countries (for example: Davis, Heathcote, 2005; Hwang, Quigley, 2006; Seko, 2003; Wen, 2001).

Mortgage banks have a small share in the mortgage loans market in Poland. Mortgages are dominated by universal banks, which hold over $98 \%$ of all housing loans. The housing market cycle has a small impact on the Polish banking system. Despite some disadvantages on the market, there has been no price bubble, 
because of permanent impediments on supply and demand. Also, supervisory recommendations were implemented on time (Lissowska, Szufler, 2012).

The polish property market has not gone through the full housing cycle yet. In fact, it is a young market. It is in its first periods of a cycle in comparison with U.S. or some European markets. Nevertheless it is highly vulnerable to financial market behavior and both fiscal and monetary policies (Łaszek et al., 2009).

The impact of interest rates on housing supply is significant, especially in the case of long-term relationship (Augustyniak et al., 2013). It is expected (BrzozaBrzezina, 2005) that in the case of euro adoption there would be a significant increase in loans. The impact of euro adoption on the housing market is an interesting question by itself. Generally, they are low interest rates (required by Maastricht criteria), which influence the credit boom (Eichengreen, Steiner, 2008). On the other hand, interest rates are still quite low. This is due to the expectation of euro adoption and the reaction to the recent financial crisis. For example, such a situation has occurred in Slovakia (Hüfner, 2009). If long-term expenditures exceed incomes, there must be a moment when severe reduction in expenditures will happen. A recession may begin as a result. Moreover, even if wages would increase, it would be naturalized by interest costs. In other words: credit can boost both economic growth and recession (Rytelewska, Huszczonek, 2004). Aggressive lending instruments magnify the cycle (Pavlov, Wachter, 2006; Tsatsaronis, Zhu 2004).

\section{Methodology and Data}

In order to maintain clarity, abbreviations of all analyzed variables are presented in Table 1.

Table 1 Explanation of variables

\begin{tabular}{l|l}
\hline CONC & assets of 5 biggest banks / total banking assets \\
\hline AS & log of total banking assets \\
\hline NI & log of net income of banking sector \\
\hline NIC & log of non-interest costs of banking sector \\
\hline NIR & log of non-interest revenues of banking sector \\
\hline BR & number of branches of banks \\
\hline EMP & number of people employed in banking sector \\
\hline EMPH & number of people employed in headquarters of banks \\
\hline PCRED & average credit rate - reference rate \\
\hline PnCRE & average rate for new credits - reference rate \\
\hline
\end{tabular}




\begin{tabular}{l|l}
\hline PCRED_H & average rate for credits for households - reference rate \\
\hline PnCRED_H & average rate for new credits for households - reference rate \\
\hline PCONS_H & average rate for consumption credits for households - reference rate \\
\hline PnCONS_H & average rate for new consumption credits for households - reference rate \\
\hline PDEP & average rate for deposits - reference rate \\
\hline PnDEP & average rate for new deposits - reference rate \\
\hline PMORT & average housing loan rate - reference rate \\
\hline PnMORT & average rate for new housing loan - reference rate \\
\hline CRED & average credit rate \\
\hline RR & reference rate \\
\hline
\end{tabular}

Source: Own elaboration

Kozak (2008) has noticed that the difference between credit rate and reference rate (see also Rousseas, 1985) increases slightly, if concentration increases. The research has been done for U.S. market between 1994 and 2005. Also, some other factors have been considered in the constructed model. Therefore in this paper a similar (but not the same) methodology is adopted, but for the Polish market. For example, in the case of the U.S., Berger and Hannan (1989) have found that the increase in concentration decreases the deposit rate in comparison with the reference rate. Similar conclusions have been stated by Hannan and Prager (1998) and Rhoades (1996). On the other hand, Erel (2011) has argued that the concentration allows banks to use their capital more efficiently and therefore margins on loans can be smaller.

Various ratios can be applied in order to measure the bank concentration ratio. The choice is usually based on the individual needs and data availability. There is no privileged choice of the ratio. One possibility is to consider CR5. CR5 is called the concentration ratio of the five biggest banks. The concentration itself is measured for example by the share in total assets (Rogowski, 2001).

This research is based on monthly date from the period between 31.12.2009 and 30.11.2013. The date has been possessed from KNF (2013) and NBP (2013) official statistics. Calculations and graphs have been done in GRETL.

\section{Analysis}

It can be observed that the concentration (CONC) has significantly increased in the analyzed period. However, it has been fluctuating between 2010 and 2012, but the real increase happened in 2012 and 2013. This increase is not great in 
absolute values. Moreover, it should be noticed that this value is rather small in comparison to other European countries.

There is also a significant increase in the number of branches during the analyzed period. It is worthwhile to mention that the two biggest market players have relatively many branches, whereas other banks have rather few branches.

On the other hand, the number of people employed in the banking sector increased in 2010 and in the first half of 2011, but then it started to decrease. Currently, this number is similar to that from the beginning of 2010. However, there is a continuous and significant trend in increasing employment in banks' headquarters. Details for the general characteristics of the banking sector are presented on Figure 1.

Figure 1 General characteristics for the analyzed period

CONC

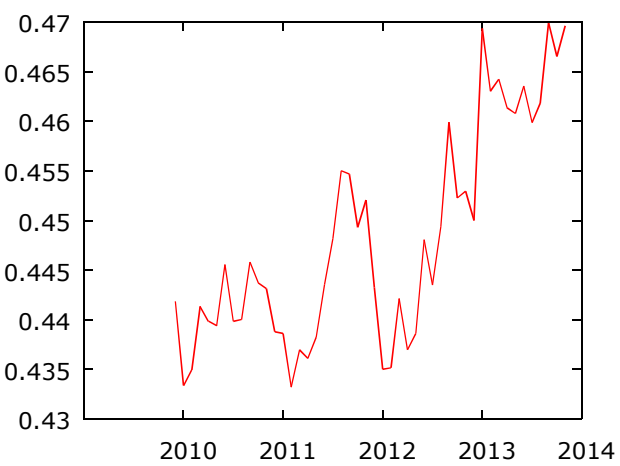

EMP

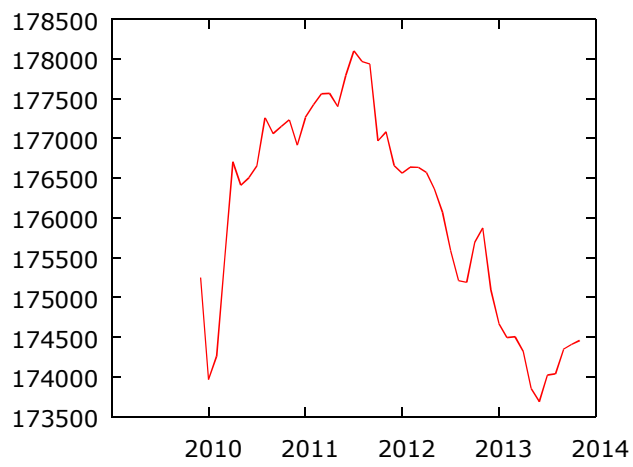

BR

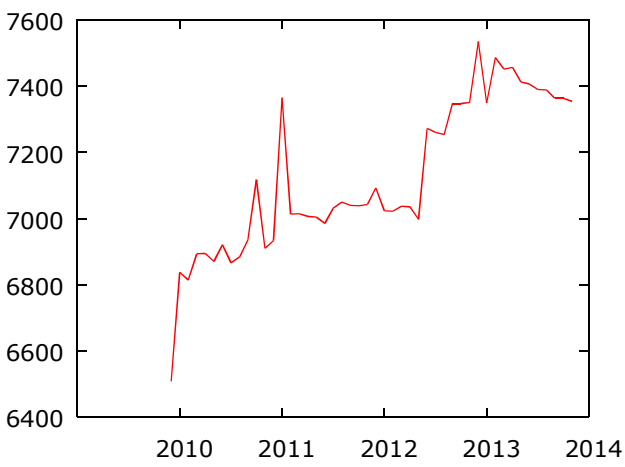

EMPH

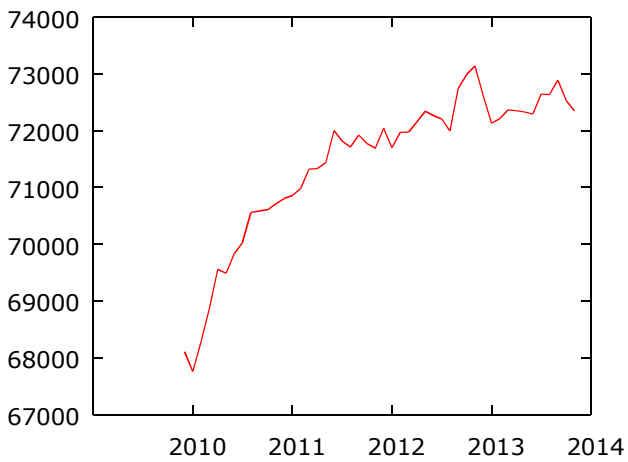

Source: Author's elaboration in GRETL, based on KBN (2013) and NBP (2013)

The average credit rate has fallen by almost $2.38 \mathrm{pp}$. in the analyzed period. This is due to the Monetary Policy Council's reaction to the recent financial crisis. It can also be observed that average credit rate behaves as the reference rate. 
There seems to be no delay in reducing credit rates by commercial banks after the Monetary Policy Council's decisions about the level of the reference rate.

Further, in this paper, it will be verified, whether the difference between the interest rate for different types of credits and the reference rate is somehow influenced by concentration ratio (and some other factors). However, it is interesting that this difference declines with time. Therefore, even though, the concentration increases, the markup of banks decreases. Details are presented on Figure 2. For other interest rates, please see Figures 3 and 4 in Appendix.

Figure 2 Average credit rate, reference rate and selected markups
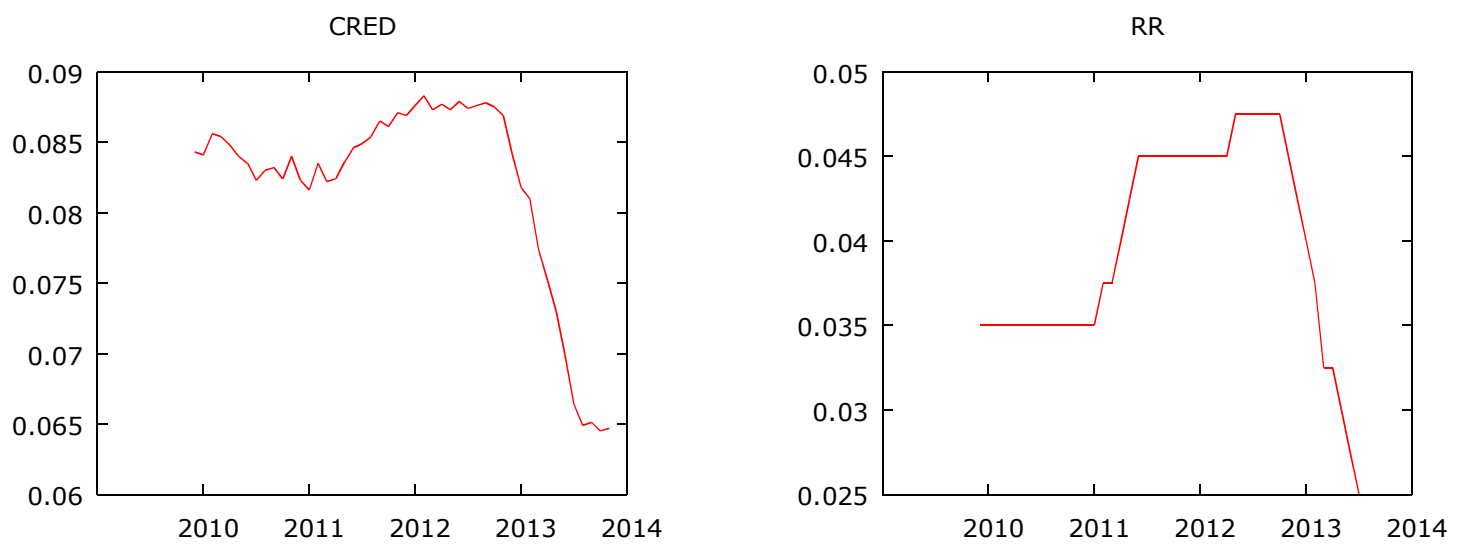

PCRED
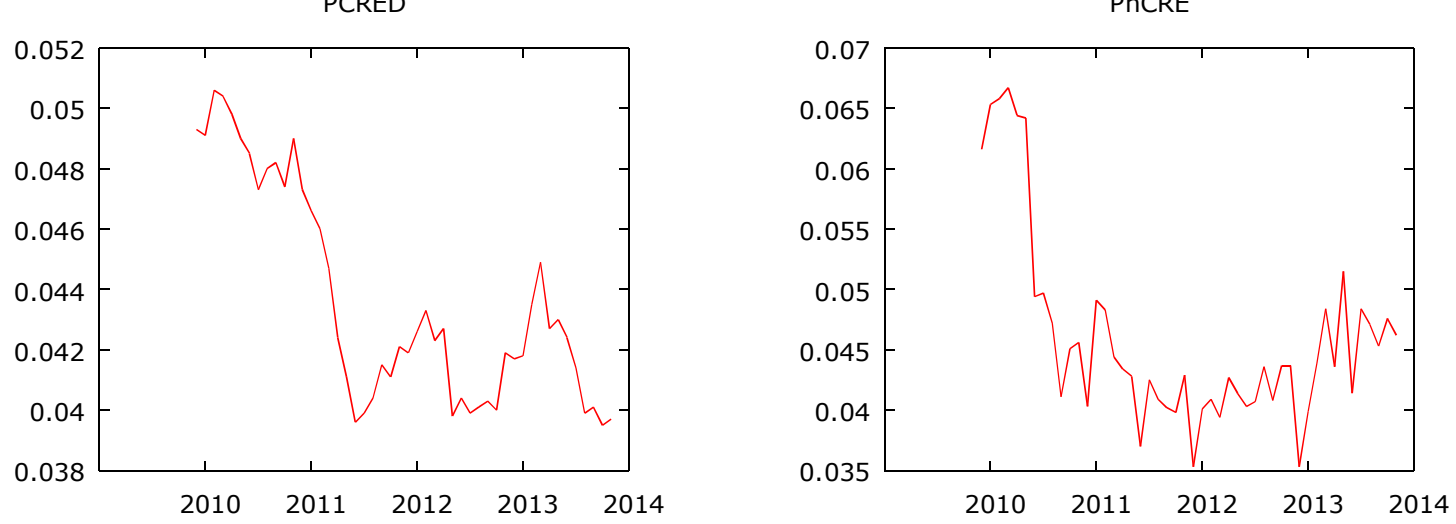

Source: Author's elaboration in GRETL, based on NBP (2013)

Moreover, at a $5 \%$ significance level non-stationarity of CONC cannot be rejected in the case of the ADF (augmented Dickey-Fuller) test (Adkins, 2010). Therefore it is reasonable to state that the concentration increased and that this is not a random effect, indeed. (In this analysis 12 lags have always been used in any 
performance test that requires some number of lags. This is because monthly data are considered.)

However it is interesting that performing ADF tests at a $5 \%$ significance level allows rejection of the null hypothesis of non-stationarity of PCRED, but not for PnCRE. Repeating the ADF test for other markups leads to the conclusion that PnCRED_H, PnCONS_H, PnMORT, PDEP and PnDEP are non-stationary, whereas PCRED_H, PCONS_H and PMORT are stationary.

This is quite a reasonable result. Markups on average rates are stationary, so there is no significant trend in their time evolution. As a result, they are suitable variables for a regression model. On the other hand, markups for new loans are non-stationary, i.e. some trends are significant. It might be, for example, due to the recent financial crises and changes in credit policies. However, such variables, if unmodified, cannot be used in a regression model. Using them can give "spurious regression". In other words: a nicely looking model can be obtained (with high R-squared), but there might be no causal connection between the variables (Granger, Newbold, 1974; Parker, 2013; Nielsen 2005).

The only exception from the above regularity is deposit rate, for which both average and recent rates are non-stationary.

Similarly as in the paper by Kozak (2008), it can be supposed that the considered markups are influenced by concentration of the banking sector, total banking assets, net income of banking sector, non-interest costs and non-interest revenues of the banking sector, number of branches and number of people employed in the whole sector and in headquarters. Such a relation can be motivated by economics theory.

Therefore linear regression models have been constructed for all previously considered markups. Stepwise regression with backward elimination (Cody, 2011) has been performed. A ten percent significance level has been assumed for significance of coefficients.

The results are presented in Table 2. For results of "spurious regression" please see Tables 4 and 5 in the Appendix. It is interesting that in both cases (stationary and non-stationary) the signs of coefficients are the same. The only exception are coefficients for NIC and BR and one exception for AS.

The obtained models explain changes in the dependent variables quite well (high R-squared). In three models out of four the concentration ratio has a significant and positive impact on bank markups. On the other hand, an increase in total banking assets or in net income has the opposite effect. The other variables are significant only in half of the obtained models. EMPH is not significant for any model. 
Table 2 Regression estimates

\begin{tabular}{c|c|c|c|c}
\hline & PCRED & PCONS_H & PCRED_H & PMORT \\
\hline Const & 0.419416 & 0.77408 & 1.01214 & 0.0970906 \\
\hline CONC & 0.0616278 & 0.0990081 & 0.0635673 & 0 \\
\hline AS & -0.0132696 & -0.0262868 & -0.0341119 & 0 \\
\hline NI & -0.0136716 & -0.0141661 & -0.0160369 & -0.0093258 \\
\hline NIR & 0.0120637 & 0 & 0.0142652 & 0 \\
\hline NIC & 0 & 0.0124601 & 0 & 0.00829045 \\
\hline BR & 0 & $7.15246 \mathrm{e}-06$ & 0 & $3.2849 \mathrm{e}-06$ \\
\hline EMP & 0 & 0 & 0 & $-4.49147 \mathrm{e}-07$ \\
\hline EMPH & 0 & 0 & 0 & 0 \\
\hline R-squared & 0.849796 & 0.663869 & 0.929218 & 0.564381 \\
\hline
\end{tabular}

Source: Author's elaboration in GRETL, based on KNF (2013) and NBP (2013)

Unfortunately, it has to be remembered that CONC is non-stationary. Moreover, the problem of stationarity is present for other independent variables. In fact, using a simple linear regression model becomes questionable, because it is desired that all variables included in a model are stationary. The discussed relationship between selected variables should be checked with some other methods for example, a cointegration property methods (Engle, Granger, 1987; Granger, 1981; Adkins, 2010) can be applied. On the other hand, the constructed models are still worth a short discussion. At least, variables have not been selected without any economic reasoning. Therefore, as far as now, the obtained models should be treated as "dangerous" rather than "completely wrong" (see also Diebold, 2006). The specification of the models has been based on some presumptions, indeed.

Jarque-Bery test for normality of distribution of residuals for a PCRED model, at $5 \%$ significance level, confirms that residuals have a normal distribution. The same conclusion is valid for PCONS_H, PCRED_H and PMORT models. This fact is a desired one for a regression model. Unfortunately, the RESET test for model linear specification confirms that PCRED and PCONS_H are badly specified. On the other hand, models for PCRED_H and PMORT can be assumed linear. The BreushPagan test confirms that residuals in all models are homoscedastic. This is a nice property for a linear regression model. The Breusch-Godfrey test for autocorrelation (up to 12th order) of residuals indicated some slight problems for all models. In all tests $5 \%$ significance level has been assumed. Finally, all models have small Durbin-Watson statistics, which together with high R-squared, can be a sign of the mentioned "spurious regression" (Granger, Newbold, 1974).

Moreover, it can be concluded from the obtained models that an increase in the concentration increases the markups. But analyzing Figures 1 and 2 leads to the 
opposite conclusion. Therefore, relying on the above discussion, the proposed linear models are not suitable in the current form. In fact, they are a good starting point for future research. Yet, it is known that a simple linear regression for non-transformed variables will not work well.

The aim of this paper is to discuss the relationship between bank markups and concentration ratio. Having in mind the discussed stationarity problem, the ADF test has been performed for the first differences of CONC. This time series is still non-stationarity. However, the second differences of CONC can be assumed stationary at a $10 \%$ significance level. At the same significance level: the second differences of PnCRE, the third differences of PnCONS_H, the third differences of PnCRED_H, the third differences of PnMORT, the third differences PDEP, the fourth differences of PnDEP have occurred to be the smallest order differences, which are stationary.

Therefore a collection of linear regression models with one independent variable (second differences of CONC) has been constructed. The results are presented in Table 3.

Table 3 Regression estimates

\begin{tabular}{|c|c|c|c|c|}
\hline & PCRED & $\begin{array}{l}\text { 2nd diff. } \\
\text { PnCRE }\end{array}$ & PCRED_H & $\begin{array}{c}\text { 3rd diff. } \\
\text { PnCRED_H }\end{array}$ \\
\hline const & $0.0434021 * * *$ & $-8.5332 e-05$ & $0.052905 * * *$ & $3.05535 e-05$ \\
\hline 2nd diff. CONC & 0.0174392 & -0.101564 & 0.0232228 & -0.113636 \\
\hline \multirow[t]{2}{*}{ R-squared } & 0.002068 & 0.013386 & 0.001504 & 0.008238 \\
\hline & PCONS_H & $\begin{array}{c}\text { 3rd diff. } \\
\text { PnCONS_H }\end{array}$ & PMORT & $\begin{array}{l}\text { 3rd diff. } \\
\text { PnMORT }\end{array}$ \\
\hline const & $0.106097 * * *$ & $-1.7897 e-05$ & $0.0230934 * * *$ & $1.44846 \mathrm{e}-05$ \\
\hline 2nd diff. CONC & 0.00521318 & -0.321364 & 0.00911311 & $0.0962809 *$ \\
\hline \multirow[t]{2}{*}{ R-squared } & 0.000148 & 0.038514 & 0.001607 & 0.067015 \\
\hline & $\begin{array}{l}\text { 3rd diff. } \\
\text { PDEP }\end{array}$ & $\begin{array}{l}\text { 4th diff. } \\
\text { PnDEP }\end{array}$ & & \\
\hline const & $7.36908 \mathrm{e}-05$ & $3.17044 \mathrm{e}-05$ & & \\
\hline 2nd diff. CONC & -0.0104519 & $0.2388 * * *$ & & $\begin{array}{c}* 10 \% \\
\text { significance } \\
\text { level }\end{array}$ \\
\hline R-squared & 0.001312 & 0.208785 & & $\begin{array}{c}* * * 1 \% \\
\text { significance } \\
\text { level }\end{array}$ \\
\hline
\end{tabular}

Source: Author's elaboration in GRETL, based on KNF (2013) and NBP (2013) 
The obtained models have very small R-squared values. However, this might be mainly due to the use of just one independent variable. In most of the models, the coefficient for the independent variable is statistically not significant at the $5 \%$ significance level. However, in the model for the 3rd differences of PnMORT and 4th differences of PnDEP the independent variable is significant, indeed. These models indicate that there is a positive relationship between bank markup and concentration ratio. Unfortunately, none of the models is significant as a whole.

\section{Conclusions}

The methods used in this paper do not indicate that the concentration of the banking sector results in the increase of the difference between offered loan rates and the reference rate. Although, from the constructed models there is a weak indication that it might happen, but the models itself are questionable.

The problems that have emerged during the regression diagnostic are mainly connected with non-stationarity of variables. Of course, such problems are workable (Adkins, 2010; Cody, 2011; Engle, Granger, 1987; Granger, 1981; Nielsen, 2005; Parker, 2013). However, they need quite more subtle methodology than simple linear regression. Therefore it is not possible to give a quick and simple answer for the problem analyzed in this paper. In fact, it has been proved that more sophisticated methods are a must.

On the other hand, graphical analysis tends to indicate that there is a weak negative relationship between the concentration of the banking sector and the difference between offered loan rates and the reference rate. Therefore, as far as now, it cannot be answered what is this relationship actually. Further research is necessary.

It could be asked, why such a short period has been used for the analysis. The Polish banking sector, understood as part of a capitalist economy, is a young one. Poland has been a member of the European Union since 2004. Three years after this transition, the global financial crisis started. Also, banking law (itself, but also recommendations, etc.) has been changed quite often. These facts influenced the banking system strongly. Therefore any analysis of a longer period should include these factors. It does not seem to be possible in a reasonably short paper.

In consideration of the above facts, it should be mentioned that banks advantage over consumers may be not solely from markups on rates. In the case of the recent crisis and worsening of households' financial conditions, banks might lower markups, but worsen some terms and conditions. Moreover, in the case of a loan, the markup on the rate is not the only source of the bank's profits. There are other costs as well. 
The data required to perform these additional analyses are not easily accessible. Moreover, research focusing on terms and conditions should be more qualitative rather than quantitative. This makes the whole problem more complex.

\section{References}

Adkins, L. C. (2010). Using gretl for Principles of Econometrics, Oklahoma State University.

Allen, J., Clark, R., Houde, J.-F. (2012). Price Competition and Concentration in Search and Negotiation Markets: Evidence from Mortgage Lending. Bank of Canada Working Paper, 2012-4.

Allen, F., Gale, D. (2000). Comparing Financial Systems, MIT Press.

Allen, F., Gersbach, H., Krahnen, J.-P., Santomero, A. M. (2001). Competition Among Banks: Introduction and Conference Overview. European Finance Review, 5, pp. 1-11.

D'Arista, J. (2009). Financial Concentration. Wall Street Watch Working Paper, 3.

Augustyniak, H., Laszek, J., Olszewski, K., Waszczuk, J. (2013). Modelling of cycles in the residential real estate market - interactions between the primary and the secondary market and multiplier effects. National Bank of Poland Working Papers, 143.

Beck, T., Demirgüç-Kunt, A., Levine, R. (2003). Bank Concentration and Crises. NBER Working Paper, 9921.

Berger, A. N., Hannan, T.H. (1989). The price-concentration relationship in banking. The Review of Economics and Statistics, 71, pp. 291-299.

Bergstresser, D. (2008). Market Concentration and Commercial Bank Loan Portfolios. Available at SSRN: http://ssrn.com/abstract $=1291356$.

Brzoza-Brzezina, M. (2005). Lending Booms in the new EU Member States. Will Euro Adoption Matter?. European Central Bank Working Papers, 543.

Calza, A., Monacelli, T., Stracca, L. (2013). Housing Finance and Monetary Policy. Journal of the European Economic Association, 11, pp. 101-122.

Carletti, E., Hartmann, P. (2002). Competition and Stability: What's Special About Banking?. European Central Bank Working Papers, 146.

Chetty, R., Szeidl, A. (2004). Consumption commitments and asset prices. Paper presented at the 2004 SED Meeting.

Cipollini, A., Fiordelisi, F. (2008). The impact of bank concentration on financial distress: the case of the European banking system, Preprint (Preliminary version).

Cody, R. (2011). SAS Statistics by Example, SAS Institute. 
Davis, M., Heathcote, J. (2005). Housing and the business cycle. International Economic Review, 46, pp. 751-784.

Diebold, F. X. (2006). Elements of forecasting, Cengage Learning.

Eichengreen, B., Steiner, K. (2008). Is Poland at Risk of a Boom-and-Bust Cycle in the Run-Up to Euro Adoption?. NBER Working Paper, 14438.

Engle, R., Granger, C. (1987). Co-integration and error correction: representation, estimation, and testing. Econometrica, 55, pp. 251-276.

Erel, I. (2011). The Effect of Bank Mergers on Loan Prices: Evidence from the United States. Review of Financial Studies, 24, pp. 1068-1101.

Favara, G., Imbs, J.M. (2010). Credit Supply and the Price of Housing. CEPR Discussion Paper, 8129.

Ferreira, C. (2013). Bank market concentration and bank efficiency in the European Union: a panel Granger causality approach. International Economics and Economic Policy, 10, pp. 365-391.

Fisher, I. (1933). The debt-deflation theory of great depressions. Econometrica, 1, pp. 337-357.

Garmaise, M. J., Moskowitz, T. J. (2004). Bank mergers and crime: The real and social effect of credit market competition. NBER Working Paper, 11006.

González, V. M., González, F. (2008). Influence of bank concentration and institutions on capital structure: New international evidence. Journal of Corporate Finance, 14, pp. 363-375.

Granger, C. (1981). Some properties of time series data and their use in econometric model specification. Journal of Econometrics, 16, pp. 121-130.

Granger, C., Newbold, P. (1974). Spurious regressions in econometrics. Journal of Econometrics, 2, pp. 111-120.

Greenwood, J., Hercowitz, Z. (1991). The allocation of capital and time over the business cycle. Journal of Political Economy, 99, pp. 1188-1214.

Hannan, T. H., Prager, R. A. (1998). Do substantial horizontal mergers generate significant price effects? Evidence from the banking industry. Journal of Industrial Economics, 46, pp. 433-452.

Herring, R. J., Wachter, S. (1998). Real Estate Booms and Banking Busts: An International Perspective. Paper presented at the Wharton Conference on Asian Twin Financial Crises 1998.

Hüfner, F. (2009). Adjusting Housing Policies in Slovakia in Light of Euro Adoption. OECD Economics Department Working Papers, 682. 
Hwang, M., Quigley, J. (2006). Economic fundamentals in local housing markets: evidence from U.S. metropolitan regions. Journal of Regional Science, 46, pp. 425-453.

Iacoviello, M. (2002). House Prices and Business Cycles in Europe: a VAR Analysis. Boston College Working Papers in Economics, 540.

KNF (2013). Dane o rynku. Available from http://www.knf.gov.pl/opracowania/ sektor_bankowy/index.html.

Kokoszczyński, R. (2001). Structural changes in the Polish banking industry three dimensions of consolidation processes in an emerging economy. BIS Papers 4 - The banking industry in the emerging market economies: competition, consolidation and systemic stability, pp. 118-122.

Kozak, S. (2008). Wpływ konsolidacji i koncentracji sektora bankowego na poziom cen w bankach. Przykład Stanów Zjednoczonych. Ekonomia, 21, pp. 120-138.

Kraciuk, J. (2006). Procesy konsolidacji w polskim sektorze bankowym. Problemy Rolnictwa Światowego, 15, pp. 282-292.

Lakic, S. (2013). Concentration in banking - A paradigm of manipulative control and power. Montenegrin Journal of Economics, 9, pp. 53-62.

Levine, R. (2004). Denying Foreign Bank Entry: Implications for Bank Interest Margins. In: (eds.) Ahumada, L.A., Fuentes, J.R., Central Banking, Analysis, and Economic Policies, Vol. 7, pp. 271-292.

Lissowska, M., Szulfer, J. (2012). Cykl mieszkaniowy a system bankowy przypadek Polski. Prace i Materiały Instytutu Rozwoju Gospodarczego SGH, 88, pp. 85-118.

Łaszek, J., Augustyniak, H., Widłak, M. (2009). Euro a ryzyko bąbli na rynku nieruchomości mieszkaniowych. Materiały i Studia NBP, 238.

Micek, M. (2002). Teoretyczne podstawy konsolidacji w sektorze bankowym. Bank i Kredyt, 33, pp. 40-46.

NBP (2013). Statystyka stóp procentowych. http://www.nbp.pl/home.aspx?f=/ statystyka/pieniezna_i_bankowa/oprocentowanie.html.

Nielsen, H. B. (2005). Lecture Notes on Econometrics 2, Københavns Universitet.

Parker, J. A. (2013). Lecture Notes on Theory and Practice of Econometrics, Reed College.

Pawłowska, M. (2003). Wpływ zmian w strukturze polskiego sektora bankowego na jego efektywność w latach 1997-2002 (podejście nieparametryczne). Bank $i$ Kredyt, 11/12, pp. 51-65. 
Pavlov, A., Wachter S. (2006). Aggressive Lending and Real Estate Markets. The Wharton School - University of Pennsylvania Working Paper, 566.

Piocha, S., Radlińska, K. (2010). Uwagi na temat kryzysu gospodarczego i sektora bankowego w Polsce. Zeszyty Naukowe Polityki Europejskie, Finanse i Marketing, 53, pp. 238-251.

Renaud, B. M. (2009). Mortgage Finance in Emerging Markets: Constraints and Feasible Development Paths. In: (eds.) Ben-Shahar, D., Leung, C.K.Y., Ong, S.E., Mortgage Markets Worldwide. Blackwell Publishing Ltd., pp. 253-288.

Rhoades, S. A. (1996). Competition and bank mergers: directions for analysis from available evidence. Antitrust Bulletin, 41, pp.339-364.

Rice, T., Strahan, P.E. (2010). Does Credit Competition Affect Small-Firm Finance. Journal of Finance, 65, pp. 861-889.

Rogowski, W. (2001). Konkurencja na rynku usług bankowych - miary koncentracji. Bank i Kredyt, 33, pp. 43-51.

Rousseas, S. (1985). A markup theory of bank loan rates. Journal of Post Keynesian Economics, 8, pp. 135-144.

Rytelewska, G., Huszczonek, E. (2004). Zmiany w popycie na kredyt gospodarstw domowych. Materiały i Studia NBP, 172.

Santillán Salgado, R. J. (2011). Banking Concentration in the European Union during the Last Fifteen Years. Panoeconomicus, 58, pp. 245-266.

Seko, M. (2003). Housing prices and economic cycles: evidence from Japanese Prefectures. Paper presented at the Nexus between the macro Economy and Housing - workshop.

Skinner, J. (1994). Housing and saving in the United States. In: (eds.) Noguchi, Y., Poterba, J., Housing Markets in the United States and Japan. University of Chicago Press, pp. 191-214.

Sørensen, C. K., Lichtenberger, J.-D. (2009). Mortgage Interest Rate Dispersion in the Euro Area. European Central Bank Working Papers, 733.

Stępień, K. (2004). Konsolidacja a efektywność banków w Polsce. CeDeWu.

Tsatsaronis, K., Zhu, H. (2004). What drives house price dynamics: cross-country evidence. BIS Quarterly Review, 03/2004, pp. 65-78.

Uhde, A., Heimeshoff, U. (2009). Consolidation in banking and financial stability in Europe: empirical evidence. IWQW discussion paper series, 02/2009.

Wen, Y. (2001). Residential investment and economic growth. Annals of Economics and Finance, 2, pp. 437-444. 


\section{Appendix}

Figure 3 Selected markups
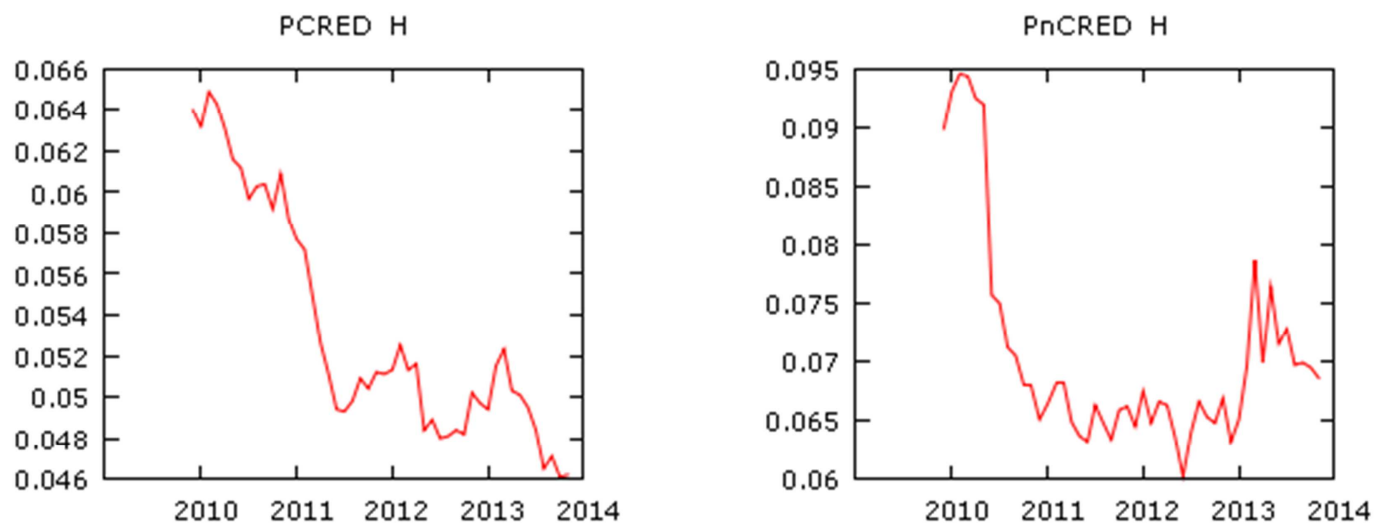

Source: Own elaboration in GRETL, based on NBP (2013) 
Figure 4 Selected markups
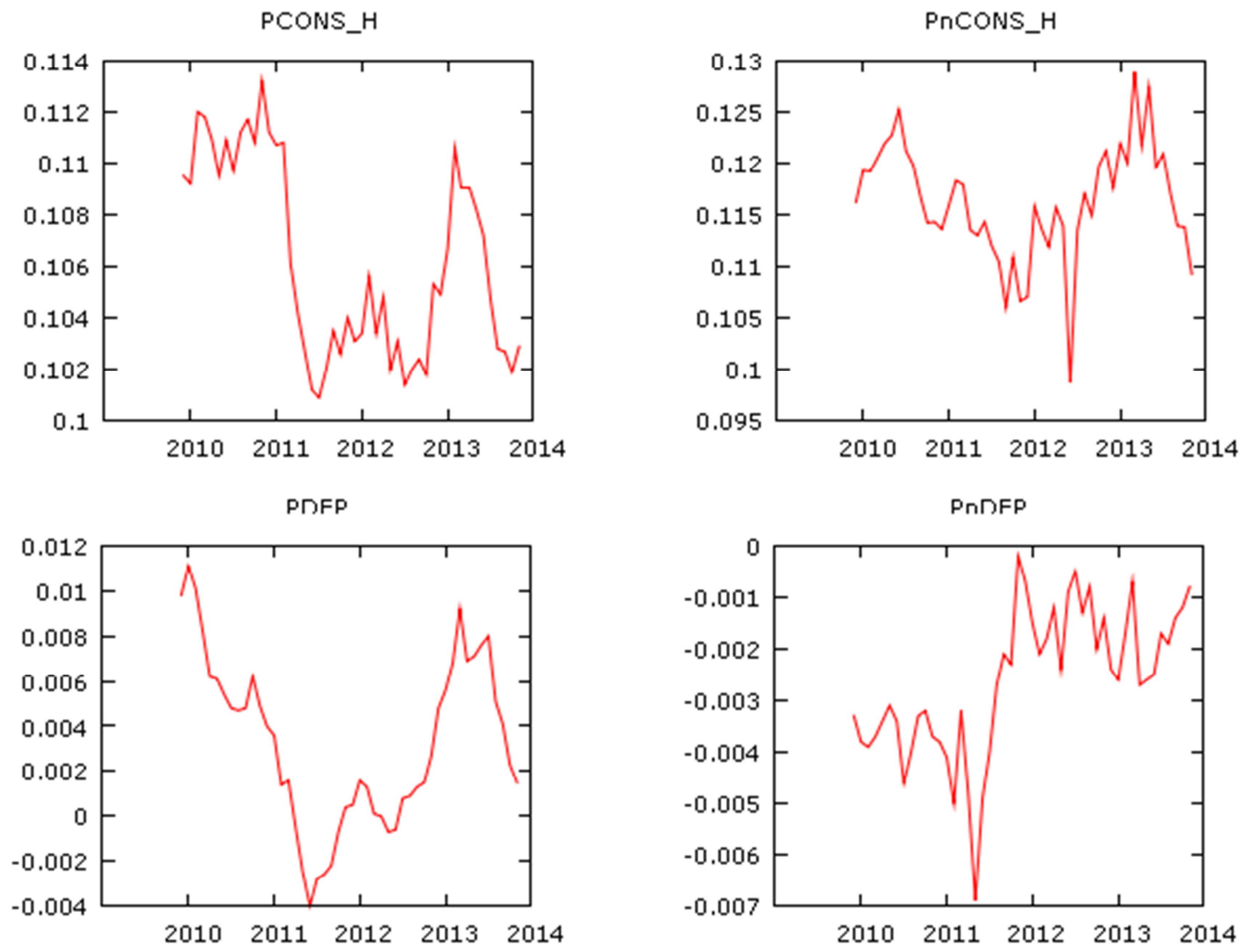

PMORT
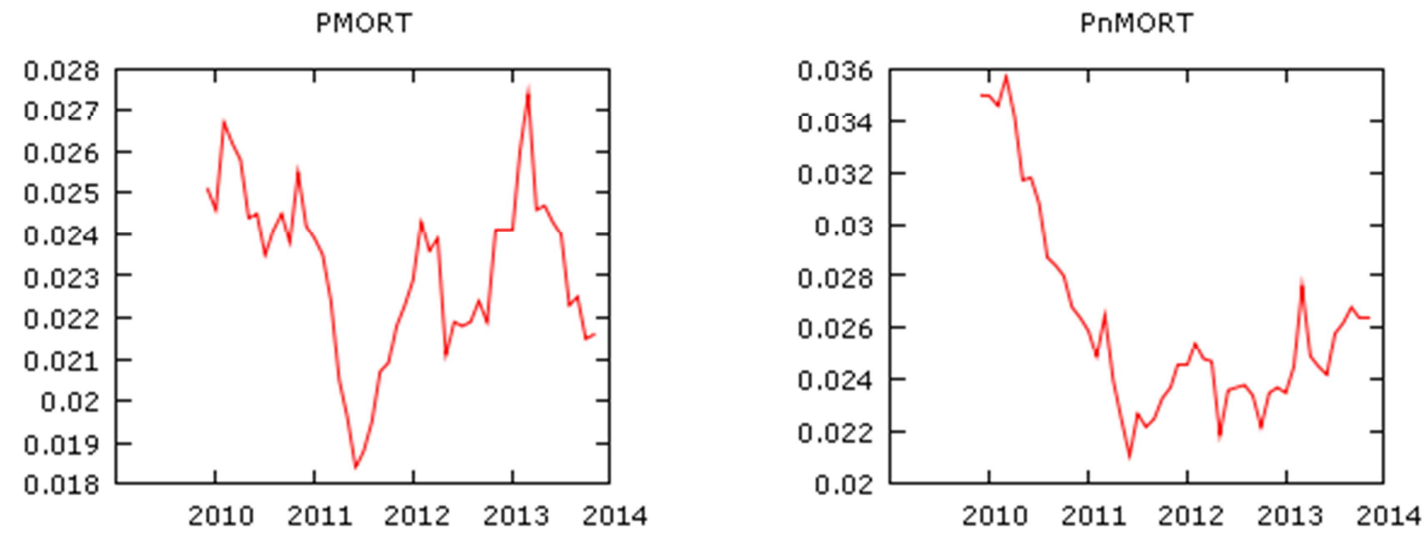

Source: Own elaboration in GRETL, based on NBP (2013) 
Table 4 Regression estimates

\begin{tabular}{c|c|c|c}
\hline & PnCRE & PnCONS_H & PnCRED_H \\
\hline const & 0.537499 & 3.64188 & 0.951073 \\
\hline CONC & 0 & 0 & 0 \\
\hline AS & 0 & -0.113996 & 0 \\
\hline NI & -0.0301861 & 0 & -0.0216027 \\
\hline NIR & 0.0863886 & 0 & 0.118207 \\
\hline NIC & -0.0601147 & -0.00230188 & -0.100298 \\
\hline BR & 0 & 0 & $-1.10765 \mathrm{e}-05$ \\
\hline EMP & $-2.18556 \mathrm{e}-06$ & $-4.22918 \mathrm{e}-06$ & $-3.87249 \mathrm{e}-06$ \\
\hline EMPH & 0 & $6.27072 \mathrm{e}-06$ & 0 \\
\hline R-squared & 0.779981 & 0.441775 & 0.833087 \\
\hline
\end{tabular}

Source: Own elaboration in GRETL, based on KNF (2013) and NBP (2013)

Table 5 Regression estimates

\begin{tabular}{c|c|c|c}
\hline & PnMORT & PDEP & PnDEP \\
\hline const & 0.228244 & 1.41527 & -0.496013 \\
\hline CONC & 0.0565545 & 0 & 0 \\
\hline AS & 0 & -0.0361382 & 0.0192108 \\
\hline NI & -0.0159656 & 0 & 0 \\
\hline NIR & 0.040111 & 0 & 0.0003818 \\
\hline NIC & -0.0257871 & 0 & 0 \\
\hline BR & $-3.22892 \mathrm{e}-06$ & $4.58485 \mathrm{e}-06$ & $-7.07141 \mathrm{e}-07$ \\
\hline EMP & $-9.09359 \mathrm{e}-07$ & $-2.48771 \mathrm{e}-06$ & 0 \\
\hline EMPH & 0 & 0 & 0.513833 \\
\hline R-Squared & 0.908702 & 0.800919 &
\end{tabular}

Source: Own elaboration in GRETL, based on KNF (2013) and NBP (2013) 